\title{
Survey of trace element and dietetic fiber composition of "Leblebi" which is a local snack food consumed in Turkey
}

\author{
Fatih ÖZBEY, Mustafa GÖRGÜLÜ²
}

\begin{abstract}
In Turkey and several Middle East countries' people consume "leblebi" which is a traditional snack food made from chickpeas (Cicer arietinum L.). Chickpea products are highly nutritive and a cheap food for human consumption and have become an essential part of daily diets in the world. The present study aims to determine the chemical, nutritional and dietary composition of fifty leblebi samples marketed in Turkey. Protein values of the leblebi ranged from 19.4 to $23.9 \%$ dehulled and 20.3 to $20.8 \%$ for nondehulled leblebi while a value of $19.1 \%$ was recorded for chickpeas. Mineral results showed that Potassium (K) was the most abundant element in leblebi ranging from 6514 to $14431 \mathrm{mg} / \mathrm{kg}$. The amount of dietary components neutral detergent fibre (NDF), acid detergent fibre (ADF), acid detergent lignin (ADL) and cellulose did not vary much between the samples analyzed.
\end{abstract}

Keywords: legumes; chickpea; leblebi; snack food.

Practical Application: Leblebi has a very low glycemic index so it can be recommended as a health snack.

\section{Introduction}

Several legumes are grown and consumed in Turkey. The chickpea is one of the common food legumes in terms of growing area and annual production in Turkey, and nearly $20 \%$ of the total chickpea production is used to produce leblebi. In Turkey legumes are the second most important source of dietary protein, calories and nutrients after cereal crops. Turkey is the fourth producer of chickpeas in the world with a production of 487,000 tons followed by India, Australia and Pakistan (Food and Agricultural Organization, 2012).

The chickpea (Cicer arietinum L.) is an important pulse crop grown and consumed all over the world. The nutritional value of the chickpea is gaining considerable interest in many countries because of the demand for healthy foods. Pulses are excellent sources of protein, starch, dietary fiber, micronutrients and bioactive compounds with a low level of fat. Globally, the chickpea (Cicer arietinum L.) is mostly consumed as a seed food in several different forms and preparations are determined by ethnic and regional factors (Vadivel et al., 2011; Jukanti et al., 2012; Aguilera et al., 2009).

Obesity continues to increase worldwide despite the efforts of governments and health care providers and reduce this trend (Miller-Brand et al., 2002). Reducing fat intake has been the primary focus of dietary prevention and treatment of overweight and obesity for many years. The glycemic index (GI) is a useful guide for choosing healthy foods, but it should not be the only one. Low glycemic index food may benefit weight control by promoting satiety. The amount of carbohydrate you take in matters too. The available carbohydrate is mainly starch which is reported to be slow digestible, thus eliciting low glycemic responses in human nutrition. Hence chickpea seeds can play an important role as a low-glyceamic functional ingredient in a healthy diet. Chickpeas are rich in total and soluble fiber as well as in resistant starch, all of which contribute to the low glycemic index of these foods.

Leblebi is a traditional snack made from roasted chickpeas common and popular in Turkey and several Middle Eastern countries. Chickpeas used for leblebi are selected for shape, size, and color and harvesting time. Generally large seeded (5-9 $\mathrm{mm}$ in diameter and 25.0-50.0 g of 100 kernel weight), lighter colored, round and smooth surfaced Kabuli chickpeas are preferred (Köksel et al., 1998; Coşkuner \& Karababa, 2004).

There are mainly two different kinds of leblebi which are dehulled (yellow leblebi, Çorum leblebi) and nondehulled (white leblebi) traditionally produced from chickpeas in different parts of Turkey. Today, leblebi is produced traditionally, which has come along traditionally thought the small-scale family plants. Producers try to increase product diversity by coating leblebi with salt, red pepper, chocolate, sugar, sesame and cloves at the final roasting stage. Furthermore, leblebi has a potential use as a natural "functional food" due to its chemical composition. They have high protein, cellulose, and mineral content, and are low in fat. Although high glycemic load it has a low Glycemic Index (GI) that's what makes leblebi a great snack compared to the sugary or high GI snacks. Leblebi has also a long shelf life due to its low moisture content, and can be stored for 6 to 12 months, depending on the packaging materials used. Better knowledge of the nutritional and organoleptic properties of leblebi would be useful in increasing the nutritional potential of chickpeas. However, very little information is available in the literature regarding the compositional components of leblebi. 
Therefore, the present study aims to investigate the compositional and mineral content of leblebi on the market in Turkey. A total of 50 dehulled and nondehulled leblebi samples were analyzed for compositional and mineral content by using standard methods.

\section{Materials and methods}

\subsection{Sampling}

Representative chickpea and leblebi samples $(n=50)$ were collected from markets in the Çorum provenience, of Turkey.

\subsection{Leblebi processing steps}

The conversion of raw chickpeas to leblebi takes approximately one and half months. The chickpeas are first sorted by size before the tempering and resting processes. Tempering takes place at $85-90^{\circ} \mathrm{C}$ for 10 to 15 minutes for penetration of moisture into the structure. After tempering, there is a long resting phase, which takes nearly 30 days at an ambient temperature. Chickpeas are kept in jute bags during the resting stage. This resting stage is very important in the leblebi quality, it is responsible for the development of the organoleptic changes expected in roasted chickpeas. After resting, first the roasting process is applied which peels away the shells of the chickpeas. The leblebi at this stage, are known as "single roasted leblebi". These half-mature products need only a final roasting two days later to be ready for sale. (Köksel et al., 1998).

\subsection{Proximate compositions, dietary fibre and mineral analysis}

For analysis, the samples were ground to flour and passed through a $350 \mu \mathrm{m}$ mesh sieve. Proximate composition was determined by measuring the fat, ash, moisture, protein $(\mathrm{N} \times 6,25)$ and carbohydrates (by difference) in triplicate using standard procedures of the Association of Official Analytical Chemist (2000). The Van Soest detergent method (Rzedzicki et al., 2008) was used to determine the content of the detergent fibre fractions (neutral detergent fibre - NDF, acid detergent fibre - ADF, cellulose-CELL and acid detergent lignin - ADL). The samples were processed using the microwave digestion technique and mineral composition was determined by atomic absorption spectrophotometer (Wang et al., 2010). The samples were quantified against standard solutions of the known concentration that were analyzed concurrently.

\subsection{Statistical analysis}

All results in this study are reported as means of three replications. The descriptive statistics were summarized and calculated using the SPSS 7.5 software.

\section{Results and discussions}

Results for the determination of proximate composition of the raw chickpea, 45 dehulled leblebi, and 4 nondehulled leblebi samples presented from the Turkey market are shown in Table 1. Legumes are considered a good source of protein. The protein content of the raw chickpea sample was $19.1 \%$, while the values of protein ranged from 19.4 to $24.0 \%$ in the leblebi. Results of the protein contents came within the normal range. The present results very in agreement with previous reports (Costa \& Monici, 2006; Ma et al., 2011; Avola et al., 2012; Sharma et al., 2013). Diversified moisture content was observed from $0.89 \%$ in the leblebi samples to $10.8 \%$ in the raw chickpea. The raw chickpea sample had significantly higher moisture contents than other leblebi samples. The results also showed that the moisture content of the dehulled leblebi samples was higher than the nondehulled leblebi samples. The ash and crude fat contents of the samples ranged between $2.30-5.92 \%$ and $5.28-8.0 \%$, respectively. Fat content of 4.61-7.79\% in chickpea seeds has been reported by Kaur et al. (2005). Ash contents of the dehulled leblebi were generally low, with the exception of the nondehullud leblebi samples which had significantly higher ash content. Previous studies have also reported significant differences in the proximate compositions of different chickpea products because of various geographic regions of the world and different processing stages of the product.

The amount of each dietary fibre components (cellulose, ADF, NDF and ADL) was determined in 50 raw chickpea and leblebi samples on a dry basis. The fibre content did not vary much between the samples analyzed. The raw chickpea contained $2.6 \%$ cellulose and $4.2 \% \mathrm{ADF}$, whereas the amounts of the NDF and ADL contents were $7.4 \%$ and $0.27 \%$ respectively and these values were more than the processed products. The dehulled and nondehulled leblebi samples have similar amount of ADL but the nondehulled leblebi samples contains more cellulose and ADF than the dehulled leblebi. Therefore, the nondehulled samples contain fewer amounts NDF than the dehulled samples (Table 2). These values showed variations from the reported values in the literature. In fact, these differences came from the processing steps of the dehulled and non dehulled leblebi, and the geographic origin of the chickpea. Chemical degradation of the dietary fibre components into glucose, arabinose, xylose and galactose might be the reasons for the reduced content of the dietary fibre components of the leblebi samples in the processing steps. These results were also in good agreement with the findings of Rehman \& Shah (2004). Similarly, many other workers also found marked decreases in dietary fibres content of various chickpeas during the cooking processes (Rehman \& Shah, 2004; Costa \& Monici, 2006). Nutrition and health experts agree that dietary fiber is important in the maintenance of health. According to the Institute of Medicine (2002), dietary reference intake, an adequate intake for total fiber, is set at 38 and $25 \mathrm{~g}$ per day for young men (age 14-50 years) and women (age 19-50 years), respectively. The Institute of Medicine defines fiber as non-digestible food plant carbohydrate and lignin that is not digested or absorbed in the human small intestine (United States Department of Agriculture, 2007).

Mineral contents of the raw chickpea, dehulled and non dehulled leblebi samples are presented in Table 3. Minerals leached from the chickpea seeds into water at different rates during the cooking treatments. Legumes are generally characterized by high minerals levels, a feature that depends on species, the agronomic cultivar and certain characteristics of the soil where the species grows. The leblebi samples contained good amounts of calcium $(\mathrm{Ca})$, zinc $(\mathrm{Zn})$, iron $(\mathrm{Fe})$ and magnesium $(\mathrm{Mg})$. These results revealed that the leblebi may provide sufficient amounts of minerals to meet the human mineral requirement (recommended 
Table 1. Chemical composition of the leblebi samples (\%)*.

\begin{tabular}{|c|c|c|c|c|c|c|c|c|c|c|c|}
\hline Sample & Moisture & Protein & Fat & Ash & ${ }^{\star}$ Carbohydrate & Sample & Moisture & Protein & Fat & Ash & ${ }^{* *}$ Carbohydrate \\
\hline $1($ Raw $)$ & 10.8 & 19.1 & 5.98 & 2.54 & 61.6 & 26 & 5.93 & 21.3 & 5.96 & 2.64 & 64.2 \\
\hline 2 & 1.51 & 21.9 & 6.99 & 2.72 & 66.9 & 27 & 2.49 & 21.6 & 5.96 & 2.61 & 67.3 \\
\hline 3 & 6.17 & 20.0 & 6.26 & 2.60 & 64.9 & 28 & 2.49 & 22.2 & 5.95 & 2.64 & 66.7 \\
\hline 5 & 1.15 & 23.3 & 6.43 & 2.37 & 66.7 & 30 & 5.25 & 21.1 & 6.20 & 2.50 & 64.9 \\
\hline 6 & 2.50 & 22.2 & 6.00 & 2.36 & 66.9 & 31 & 3.35 & 22.6 & 6.14 & 2.65 & 65.3 \\
\hline 9 & 1.09 & 22.2 & 6.73 & 2.72 & 67.3 & 34 & 4.85 & 20.7 & 5.91 & 2.72 & 65.8 \\
\hline 10 & 2.08 & 20.6 & 8.00 & 2.30 & 66.9 & 35 & 3.58 & 21.5 & 6.70 & 2.45 & 65.8 \\
\hline 11 & 1.43 & 21.2 & 7.61 & 2.49 & 67.2 & 36 & 2.25 & 20.9 & 7.65 & 2.35 & 66.9 \\
\hline 12 & 2.76 & 23.2 & 6.94 & 2.69 & 64.5 & 37 & 2.11 & 21.2 & 7.70 & 2.30 & 66.7 \\
\hline 13 & 3.66 & 20.9 & 6.98 & 2.46 & 66.0 & 38 & 4.23 & 22.1 & 6.92 & 2.67 & 64.1 \\
\hline 18 & 2.55 & 22.1 & 6.75 & 2.42 & 66.2 & 43 & 3.05 & 20.4 & 6.85 & 2.77 & 66.9 \\
\hline 19 & 2.44 & 21.5 & 7.10 & 2.69 & 66.3 & 44 & 5.38 & 20.5 & 7.90 & 2.46 & 63.8 \\
\hline 20 & 1.75 & 22.9 & 6.01 & 2.50 & 66.9 & 45 & 3.31 & 20.8 & 7.85 & 5.92 & 62.1 \\
\hline 21 & 2.46 & 23.1 & 5.69 & 2.67 & 66.1 & 46 & 7.53 & 20.3 & 7.14 & 2.49 & 62.6 \\
\hline 22 & 3.07 & 21.9 & 6.53 & 2.55 & 65.9 & 47 (nondehulled) & 3.79 & 20.7 & 5.39 & 5.40 & 64.7 \\
\hline 23 & 1.59 & 22.1 & 6.64 & 2.45 & 67.2 & 48 (nondehulled) & 4.45 & 20.9 & 5.67 & 4.65 & 64.4 \\
\hline 24 & 0.89 & 22.8 & 6.28 & 2.50 & 67.6 & 49 (nondehulled) & 4.44 & 20.6 & 5.28 & 4.76 & 64.9 \\
\hline 25 & 5.00 & 21.6 & 5.55 & 2.62 & 65.2 & 50 (nondehulled) & 5.50 & 20.3 & 5.88 & 4.48 & 63.8 \\
\hline
\end{tabular}

${ }^{\star}$ Average of three determinations. ${ }^{* *}$ Obtained by difference.

Table 2. Dietary fibers content of the leblebi samples \% (dry basis)*.

\begin{tabular}{|c|c|c|c|c|c|c|c|c|c|}
\hline Samples & Cellulose & ADF & NDF & ADL & Samples & Cellulose & ADF & NDF & ADL \\
\hline 1(Raw) & 2.6 & 4.20 & 7.40 & 0.27 & 26 & 2.8 & 3.49 & 16.43 & 0.54 \\
\hline 2 & 3.0 & 4.52 & 16.03 & 1.11 & 27 & 2.2 & 2.85 & 10.01 & 0.33 \\
\hline 3 & 2.5 & 4.23 & 10.55 & 1.16 & 28 & 3.9 & 3.48 & 15.49 & 0.71 \\
\hline 4 & 3.0 & 4.00 & 12.06 & 0.71 & 29 & 2.0 & 2.95 & 13.56 & 0.58 \\
\hline 5 & 2.6 & 4.18 & 13.77 & 0.86 & 30 & 7.2 & 2.46 & 17.61 & 0.61 \\
\hline 6 & 2.2 & 4.28 & 13.6 & 1.12 & 31 & 2.5 & 3.05 & 15.15 & 0.52 \\
\hline 7 & 2.2 & 3.35 & 13.86 & 0.90 & 32 & 2.4 & 3.03 & 16.49 & 0.79 \\
\hline 8 & 2.3 & 3.02 & 11.29 & 0.67 & 33 & 1.7 & 3.95 & 19.08 & 1.13 \\
\hline 9 & 2.3 & 2.68 & 24.94 & 0.61 & 34 & 2.7 & 4.32 & 20.02 & 1.04 \\
\hline 10 & 1.7 & 2.13 & 19.28 & 0.67 & 35 & 2.1 & 3.89 & 12.9 & 1.09 \\
\hline 11 & 2.0 & 2.75 & 14.31 & 0.84 & 36 & 2.1 & 2.38 & 11.24 & 0.86 \\
\hline 12 & 2.2 & 2.61 & 9.50 & 0.64 & 37 & 1.4 & 2.70 & 12.19 & 0.64 \\
\hline 13 & 1.9 & 3.16 & 6.99 & 0.94 & 38 & 0.9 & 2.41 & 8.14 & 0.53 \\
\hline 14 & 2.1 & 2.48 & 9.03 & 0.73 & 39 & 0.9 & 2.60 & 14.94 & 0.86 \\
\hline 15 & 2.4 & 2.17 & 8.71 & 0.49 & 40 & 2.1 & 4.17 & 8.40 & 1.04 \\
\hline 16 & 1.4 & 2.11 & 9.42 & 0.54 & 41 & 2.5 & 3.41 & 11.67 & 0.74 \\
\hline 17 & 2.1 & 2.71 & 8.35 & 0.65 & 42 & 2.1 & 3.98 & 6.24 & 0.24 \\
\hline 18 & 2.4 & 3.04 & 9.96 & 0.74 & 43 & 2.9 & 4.76 & 7.20 & 0.42 \\
\hline 19 & 2.1 & 3.13 & 16.05 & 0.75 & 44 & 0.9 & 2.06 & 4.55 & 0.54 \\
\hline 20 & 1.5 & 2.89 & 16.23 & 0.83 & 45 & 1.1 & 3.17 & 7.69 & 1.08 \\
\hline 21 & 1.8 & 2.88 & 9.65 & 0.73 & 46 & 1.3 & 3.41 & 3.48 & 0.85 \\
\hline 22 & 1.8 & 3.51 & 6.53 & 0.90 & 47 (nondehulled) & 2.6 & 4.67 & 5.61 & 0.60 \\
\hline 23 & 2.8 & 3.65 & 12.09 & 1.10 & 48 (nondehulled) & 2.7 & 5.08 & 6.76 & 0.66 \\
\hline 24 & 2.5 & 3.98 & 16.71 & 0.77 & 49 (nondehulled) & 3.0 & 4.67 & 6.71 & 0.52 \\
\hline 25 & 2.7 & 4.37 & 10.79 & 0.81 & 50 (nondehulled) & 2.3 & 5.12 & 6.25 & 1.28 \\
\hline
\end{tabular}

*Average of tree determinations of every samples. 
Table 3. Mineral contents of the raw chickpea, dehulled and nondehulled leblebi samples.

\begin{tabular}{|c|c|c|c|c|c|c|c|c|}
\hline Sample & $\mathrm{Cu}\left(\mathrm{mg} \cdot \mathrm{kg}^{-1}\right)$ & $\mathrm{Fe}\left(\mathrm{mg} \cdot \mathrm{kg}^{-1}\right)$ & $\mathrm{Zn}\left(\mathrm{mg} \cdot \mathrm{kg}^{-1}\right)$ & $\mathrm{K}\left(\mathrm{mg} \cdot \mathrm{kg}^{-1}\right)$ & $\mathrm{Na}\left(\mathbf{m g} \cdot \mathrm{L}^{-1}\right)$ & $\operatorname{Mn}\left(\mathrm{mg} \mathrm{L}^{-1}\right)$ & $\operatorname{Mg}\left(\mathbf{m g} \cdot \mathrm{L}^{-1}\right)$ & $\mathrm{Ca}\left(\mathrm{mg} \cdot \mathrm{L}^{-1}\right)$ \\
\hline 1(Raw) & 3.32 & 48.69 & 56.62 & 8441 & 58.24 & 16.49 & 1151 & 1277 \\
\hline 2 & 16.64 & 59.34 & 73.07 & 27122 & 102.64 & 15.73 & 2083 & 547 \\
\hline 3 & 26.45 & 54.53 & 72.71 & 11038 & 67.94 & 13.82 & 987 & 548 \\
\hline 4 & 17.51 & 55.78 & 80.80 & 12718 & 77.86 & 14.99 & 999 & 525 \\
\hline 5 & 12.88 & 47.72 & 70.49 & 11138 & 66.48 & 15.02 & 905 & 581 \\
\hline 6 & 14.70 & 51.40 & 73.31 & 12768 & 87.52 & 15.22 & 1982 & 286 \\
\hline 7 & 14.97 & 52.84 & 86.98 & 8399 & 156.57 & 13.81 & 683 & 232 \\
\hline 8 & 14.80 & 51.95 & 77.19 & 66951 & 171.85 & 15.33 & 5423 & 274 \\
\hline 9 & 11.49 & 54.25 & 68.39 & 12222 & 73.27 & 14.88 & 5084 & 273 \\
\hline 10 & 12.36 & 49.65 & 69.34 & 8988 & 59.58 & 13.41 & 1011 & 294 \\
\hline 11 & 15.40 & 52.89 & 77.06 & 11621 & 94.09 & 15.35 & 843 & 291 \\
\hline 12 & 11.66 & 50.64 & 70.74 & 12441 & 96.55 & 16.09 & 1037 & 293 \\
\hline 13 & 13.21 & 48.51 & 72.36 & 11157 & 72.69 & 14.10 & 1266 & 331 \\
\hline 14 & 10.69 & 47.61 & 64.59 & 13040 & 82.98 & 15.88 & 1068 & 770 \\
\hline 15 & 10.25 & 50.03 & 74.05 & 12683 & 143.42 & 15.06 & 948 & 583 \\
\hline 16 & 8.97 & 44.99 & 67.19 & 14431 & 58.22 & 13.58 & 1313 & 692 \\
\hline 17 & 9.35 & 45.92 & 68.37 & 12486 & 154.65 & 15.57 & 1411 & 639 \\
\hline 18 & 8.87 & 46.27 & 67.55 & 10966 & 50.52 & 13.75 & 1043 & 687 \\
\hline 19 & 11.70 & 50.78 & 65.14 & 13536 & 70.19 & 15.74 & 1379 & 551 \\
\hline 20 & 10.53 & 58.17 & 77.54 & 11086 & 89.52 & 13.65 & 1338 & 660 \\
\hline 21 & 7.45 & 42.58 & 68.39 & 11587 & 67.31 & 14.33 & 3152 & 561 \\
\hline 22 & 8.69 & 46.01 & 64.56 & 10996 & 64.81 & 14.64 & 1903 & 551 \\
\hline 23 & 9.32 & 48.01 & 67.89 & 7982 & 112.57 & 13.71 & 765 & 716 \\
\hline 24 & 19.09 & 45.39 & 66.06 & 10330 & 70.23 & 13.97 & 2813 & 647 \\
\hline 25 & 11.74 & 57.11 & 60.70 & 11644 & 94.14 & 13.18 & 1105 & 584 \\
\hline 26 & 12.83 & 54.49 & 74.06 & 12121 & 108.46 & 15.23 & 1721 & 673 \\
\hline 27 & 8.56 & 46.60 & 67.53 & 11623 & 144.38 & 14.93 & 1402 & 642 \\
\hline 28 & 8.63 & 47.97 & 69.53 & 11639 & 111.84 & 14.57 & 1399 & 637 \\
\hline 29 & 6.25 & 47.63 & 69.59 & 10065 & 88.08 & 15.97 & 1820 & 620 \\
\hline 30 & 7.79 & 47.22 & 67.53 & 10481 & 76.20 & 14.09 & 1420 & 672 \\
\hline 31 & 9.89 & 40.62 & 58.09 & 10809 & 99.03 & 13.32 & 1204 & 532 \\
\hline 32 & 7.61 & 43.67 & 65.33 & 3695 & 90.15 & 14.71 & 521 & 625 \\
\hline 33 & 6.54 & 44.68 & 64.00 & 11312 & 162.7 & 15.88 & 1359 & 623 \\
\hline 34 & 6.21 & 44.23 & 63.26 & 8933 & 147.5 & 15.27 & 1373 & 652 \\
\hline 35 & 5.25 & 40.73 & 59.57 & 9324 & 148.4 & 13.58 & 995 & 612 \\
\hline 36 & 8.85 & 46.96 & 61.67 & 8363 & 80.93 & 11.99 & 1282 & 725 \\
\hline 37 & 6.56 & 43.49 & 56.88 & 6514 & 52.54 & 11.58 & 573 & 692 \\
\hline 38 & 5.58 & 46.17 & 57.48 & 7862 & 1478.3 & 14.50 & 645 & 577 \\
\hline 39 & 5.73 & 43.51 & 59.57 & 9634 & 146.94 & 15.12 & 1007 & 616 \\
\hline 40 & 5.88 & 48.55 & 56.38 & 10045 & 119.95 & 18.22 & 2045 & 542 \\
\hline 41 & 5.06 & 44.28 & 55.12 & 9889 & 81.56 & 15.29 & 1128 & 790 \\
\hline 42 & 3.50 & 58.81 & 52.44 & 6417 & 55.33 & 16.36 & 1108 & 1278 \\
\hline 43 & 2.63 & 57.19 & 55.12 & 7381 & 102.0 & 18.40 & 1031 & 635 \\
\hline 44 & 4.54 & 39.80 & 52.81 & 8319 & 52.25 & 11.94 & 1400 & 758 \\
\hline 45 & 5.37 & 40.05 & 52.61 & 9643 & 39.90 & 12.42 & 1643 & 664 \\
\hline 46 & 5.38 & 39.97 & 51.68 & 6985 & 43.65 & 12.65 & 967 & 678 \\
\hline 47 (nondehulled) & 2.30 & 41.90 & 51.12 & 9245 & 29132 & 15.04 & 1018 & 1025 \\
\hline 48 (nondehulled) & 2.33 & 39.06 & 46.24 & 7904 & 69.29 & 13.23 & 776 & 661 \\
\hline 49 (nondehulled) & 1.34 & 43.57 & 54.59 & 9610 & 29269 & 17.58 & 1383 & 1171 \\
\hline 50 (nondehulled) & 0.91 & 43.09 & 51.16 & 22999 & 139441 & 15.84 & 1237 & 1147 \\
\hline
\end{tabular}


dietary allowance, RDA) (Iqbal et al., 2006). Results showed that $\mathrm{K}$ was the most abundant element in leblebi ranging from 3695 to $66951 \mathrm{mg} \cdot \mathrm{kg}^{-1}$. The amount of $\mathrm{Cu}, \mathrm{Fe}, \mathrm{Zn}, \mathrm{Na}, \mathrm{Mn}, \mathrm{Mg}$ and Ca arranged from 0.91 to $26.45 \mathrm{mg} . \mathrm{kg}^{-1}, 39.06$ to $59.34 \mathrm{mg} . \mathrm{kg}^{-1}$, 46.24 to $86.98 \mathrm{mg} . \mathrm{kg}^{-1}, 39.90$ to $139441 \mathrm{mg} . \mathrm{L}^{-1}, 11.58$ to $18.40 \mathrm{mg} . \mathrm{L}^{-1}$, 521 to $5423 \mathrm{mg} . \mathrm{L}^{-1}$ and 232 to $1278 \mathrm{mg} . \mathrm{L}^{-1}$ respectively (Table 3 ). Because of the boiling solution of the nondehulled leblebi, which is prepared by dissolving sodium bicarbonate, oxalic acid and titanium dioxide in water some mineral contents were high. The mineral contents were comparable to the chickpeas reported by Wang et al. and the Canadian Pulses Commission report (Wang \& Daum, 2004; Wang et al., 2010).

The Food Authority highly recommends that organic, functional and traditional food should compose the bulk of human diet. Mainly because of their content of a number of bioactive components such as dietary fiber and other indigestible carbohydrates as well as polyphenols with in vivo antioxidant properties (Cristobal et al., 2010). The present work provides data on the content of some of these health-beneficial components in the dehulled and nondehulled leblebi.

\section{Conclusion}

Today's obesity has become a widespread problem globally; the degree of obesity has reached alarming level (Wang et al., 2010). The findings of this study demonstrate that the analyzed leblebi samples are a good source of protein. From a nutritional point of view, the two types of studied leblebi had good nutrient values with an approximate protein content of $21 \%$. The nutritional significance of these kinds of confectionary products must be introduced by mass media all over the world.

In conclusion, this study provides additional information on the chemical composition of traditional confection in Turkey. In view of the overall nutrient and the proximate composition analysis, this traditional confectionary product can be an economic and alternative protein source that improve the overall nutritional status of functional foods in the world.

\section{Acknowledgements}

The author is grateful to the Hitit University Scientific Research and Development Office for their financial support (Project no: MUH01.12.002).

\section{References}

Aguilera, Y., Martín-Cabrejas, A. M., Benítez, V., Mollá, E., LópezAndréu, J. F., Esteban, M. R. (2009). Changes in carbohydrate fraction during dehydration process of common legumes. Journal of Food Composition and Analysis, 22, 678-683.

Association of Official Analytical Chemist - AOAC. (2000). Official method of analysis (17th ed.). Washington, DC: Association of Official Analytical Chemist.

Avola, G., Patanè, C., \& Barbagallo, R. N. (2012). Effect of water cooking on proximate composition of grain in three Sicilian chickpeas (CicerarietinumL.). LWT: Food Science and Technology (Campinas.), $49,217-220$.

Cristobal, L. S., Osorio-Diaz, P., Tovar, J., \& Bello-Perez, L. A. (2010). Chemical composition, carbohydrate digestibility, and antioxidant capacity of cooked black bean, chickpea, and lentil Mexican varieties. CyTA-Journal of Food, 8(1), 7-14. http://dx.doi. org/10.1080/19476330903119218.

Costa, G. E. A., \& Monici, K. (2006). Chemical composition, dietary fibre and resistant starch contents of raw and cooked pea, common bean, chickpea and lentil legumes. Food Chemistry, 94(3), 327-330. http://dx.doi.org/10.1016/j.foodchem.2004.11.020.

Coşkuner, Y., \& Karababa, E. (2004). Leblebi: a roasted chickpea product as a traditional Turkish snack food. Food Reviews International, 20(3), 257-274. http://dx.doi.org/10.1081/FRI-200029424.

Food and Agricultural Organization - FAO. (2012). FAO Statistical databases and data sets. Rome: FAO. Retrieved from: http://www. faostat.fao.org/

Iqbal, A., Khalil, I. A., Ateeq, N., \& Khan, M. S. (2006). Nutritional quality of important food legumes. Food Chemistry, 97(2), 331-335. http://dx.doi.org/10.1016/j.foodchem.2005.05.011.

Jukanti, A. K., Gaur, P. M., Gowda, C. L. L., \& Chibbar, R. N. (2012). Nutritional quality and health benefits of chickpea (CicerarietinumL.): a review. British Journal of Nutrition, 108(S1, Suppl 1), S11-S26. http://dx.doi.org/10.1017/S0007114512000797. PMid:22916806.

Kaur, M., Singh, N., \& Sodhi, N. S. (2005). Physicochemical cooking, textural and roasting characteristics of chickpea (Cicerarietinum) cultivars. Journal of Food Engineering, 69(4), 511-517. http://dx.doi. org/10.1016/j.jfoodeng.2004.09.002.

Köksel, H., Sivri, D., Scanlon, M. G., \& Bushuk, W. (1998). Comparison of physical properties of raw and roasted chickpeas (leblebi). Food Research International, 31(9), 659-665. http://dx.doi.org/10.1016/ S0963-9969(99)00042-3.

Ma, Z., Boye, J. I., Simpson, B. K., Prasher, S. O., Monpetit, D., \& Malcolmson, L. (2011). Thermal processing effects on the functional properties and microstructure of lentil, chickpea, and pea flours. Food Research International, 44(8), 2534-3544. http://dx.doi.org/10.1016/j. foodres.2010.12.017.

Miller-Brand, C. J., Holt, H. A. S., Pawlak, B. D., \& McMilan, J. (2002). Glycemic index and obesity. The American Journal of Clinical Nutrition, 76(1, Suppl.), 281S-2855S. PMid:12081852.

Rehman, Z., \& Shah, W. H. (2004). Domestic processing effects on some insoluble dietary fibre components of various food legumes. Food Chemistry, 87(4), 613-617. http://dx.doi.org/10.1016/j. foodchem.2004.01.012.

Rzedzicki, Z., Domanska, E. S., \& Popielewicz, J. (2008). Quality of wheat breakfast cereals available on the Polish Market. Polish Journal of Food and Nutrition Science, 58(3), 307-312.

Sharma, S., Yadav, S., Singh, A., \& Kumar, R. (2013). Nutritional and anti-nutritional profile of newly developed chickpea (CicerarietinumL.) varieties. International Food Research Journal, 20(2), 805-810.

United States Department of Agriculture. (2007). The food supply and dietary fiber: its availability and effect on health: nutrition insight 36. Washington, DC: United States Department of Agriculture.

Vadivel, V., Stuetz, W., Scherbaum, V., \& Biesalski, H. K. (2011). Total free phenolic content and health relevant functionality of Indian wild legume grains: Effect of indigenous processing methods. Journal of Food Composition and Analysis, 24(7), 935-943. http:// dx.doi.org/10.1016/j.jfca.2011.04.001.

Wang, N. \& Daum, J. K. (2004). Chickpea (Cicer arietinum). In N. Wang \& J. K. Daum. The chemical composition and nutritive value of Canadian pulses (pp. 19-29). Canadian Grain Commission.

Wang, N., Hatcher, D. W., Tyler, R. T., Toews, R., \& Gawalko, E. (2010). Effect of cooking on the composition of beans (Phaseolus vulgaris L.) and chickpeas (Cicerarietinum L.). Food Research International, 43(2), 589-594. http://dx.doi.org/10.1016/j.foodres.2009.07.012. 